\title{
Paideusis
}

\section{Teaching and the Value of Inquiry}

\section{Paul O'Leary}

Volume 16, Number 2, 2007

URI: https://id.erudit.org/iderudit/1072581ar

DOI: https://doi.org/10.7202/1072581ar

See table of contents

Publisher(s)

Canadian Philosophy of Education Society

ISSN

0838-4517 (print)

1916-0348 (digital)

Explore this journal

Cite this article

O'Leary, P. (2007). Teaching and the Value of Inquiry. Paideusis, 16(2), 73-79. https://doi.org/10.7202/1072581ar
Article abstract

This paper considers a self-acknowledged indoctrinator's defense of his teaching. This defense relies on the correspondence conception of truth which allows a logical gap between the conduct of an inquiry and the truth of our beliefs. In criticism, I will seek to characterize the truth of our beliefs in terms of a link with genuine inquiry. Finally, I consider the value of having true beliefs and what constitutes the importance of acquiring the ability to inquire. On this view, good teaching, at a minimum, involves the exercise and the fostering of what I shall call epistemic prudence.
This document is protected by copyright law. Use of the services of Erudit (including reproduction) is subject to its terms and conditions, which can be viewed online.

https://apropos.erudit.org/en/users/policy-on-use/ 


\title{
Teaching and the Value of Inquiry
}

\author{
PAUL O'LEARY \\ University of Western Ontario, Canada
}

\begin{abstract}
This paper considers a self-acknowledged indoctrinator's defense of his teaching. This defense relies on the correspondence conception of truth which allows a logical gap between the conduct of an inquiry and the truth of our beliefs. In criticism, I will seek to characterize the truth of our beliefs in terms of a link with genuine inquiry. Finally, I consider the value of having true beliefs and what constitutes the importance of acquiring the ability to inquire. In this view, good teaching, at a minimum, involves the exercise and the fostering of what I shall call epistemic prudence.
\end{abstract}

...the supreme mystery of despotism, its prop and stay, is to keep men in a state of deception. ${ }^{1}$

What reasons are there for viewing students who have been indoctrinated as having been miseducated? Suppose we construe the indoctrinated state of mind in the following manner: "Because of teaching, a student believes that $\mathrm{p}$ regardless of the evidence and is disposed to reject any $\mathrm{q}$ that is offered as a countervailing consideration to believing that p." 2 Given this characterization, one complaint against being indoctrinated is that, in such a condition, a student becomes incapable of inquiry into those beliefs he or she has been taught. In being disposed to reject any countervailing consideration, no matter what its merits may be, such a student cannot reappraise his or her beliefs. When the indoctrinated beliefs touch on matters which are significant to the sort of life a student will be able to lead, being indoctrinated seriously compromises his or her ability to inquire into the truth about such matters.

The notion of indoctrination being a harmful condition in which to be is based on the idea that to inquire competently into one's beliefs provides a successful inquirer with a significant good: namely, the truth. Of course, not all truths are born equal. As Susan Haack reminds us, some "truths are boring, trivial, unimportant, not worth the effort of investigation." 3 Obviously then, not all types of inquiry are equally worth pursuing. So, too, being indoctrinated is not equally harmful in all cases. It is, however, especially harmful in cases where one is blocked from inquiry into matters which have a significant bearing on how one lives.

Despite the fact that not all truths are equally important, in having true beliefs, especially about important matters, an agent is usually thought to be better off than if he or she had false beliefs. But are

\footnotetext{
${ }^{1}$ Spinoza, Theological-Political Treatise, translated by S. Shirley (Hackett: 2002) p. 389.

2 This version of the indoctrinated state of mind is somewhat modified from my earlier formulations. See my article "Indoctrination and the Indoctrinated State of Mind" in Philosophy of Education: Canadian Perspectives, (eds.) D.B. Cochrane and M. Schiralli, (Collier MacMillan: 1982) pp. 71-82. See also my article "Indoctrinated State of Mind" in J. Coombs (ed.) Philosophy of Education: 1979 (Normal, Illinois). pp 295-303.

${ }^{3}$ Susan Haack, Manifesto of a Passionate Moderate (University of Chicago Press; Chicago; 1998) p. 13.

(C) Copyright 2007. The author, Paul O'Leary, assigns to Paideusis the right of first publication and educational and non-profit institutions a non-exclusive license to use this document for personal use and in courses of instruction provided that the article is used in full and this copyright statement is reproduced. Any other usage is probibited without the express permission of the author.
} 
we not sometimes better off with our illusions than with unvarnished and disturbing truths? Or is having true beliefs an inherent good despite their often-disturbing nature? But an indoctrinator also views true beliefs as inherently good. Moreover, he or she considers that the particular truths being taught have such a value that their maintenance must be protected at all costs. Consequently, that teacher seeks to justify fostering in his or her students a disposition to reject any countervailing considerations. For such a teacher, reappraising certain beliefs by way of inquiry is out of the question.

This paper begins by considering a self-acknowledged indoctrinator's defense of his teaching. This is done in terms of what I take to be an acceptance and use of a particular version of the correspondence conception of truth. Such a version would allow a logical gap between evidence and the truth of our beliefs. In criticizing this defense, I will not only find fault with this version of the correspondence conception of truth, but will also seek to establish a link between inquiry and truth by characterizing true beliefs in terms of the successful outcome of any genuine inquiry. In this way, the gap between evidence and truth can be bridged. Finally, I consider the value of having true beliefs. This will shed some light on the value of inquiry.

These arguments show that indoctrination, in blocking the road to inquiry, prevents students from acquiring whatever value there is in having true beliefs. Another conclusion is that good teaching, especially in areas where the chief concern is about the appropriate formation, maintenance, and revision of beliefs, requires, at a minimum, the exercise and fostering of what I shall call epistemic prudence.

\section{Truth and Inquiry}

Leaving aside questions concerning exactly what sort of beliefs have a significant bearing on the lives of human beings, how does a certain version of the correspondence conception of truth contribute to a self-acknowledged indoctrinator's defense? ${ }^{4}$ In this correspondence conception, a belief is true if, and only if, the content of a belief corresponds to its object. So then, someone's belief that it is raining is true if, and only if, it is raining. At this point we have reached the exalted level of a platitude. Nonetheless, it can offer a self-acknowledged indoctrinator some protective covering. For in viewing truth in terms of a certain conception of correspondence, we can keep the truth of our beliefs logically independent of the evidence gathered by inquiry. Consequently, while inquiry may provide sufficient support for a belief, the indoctrinator's interpretation of correspondence can logically allow that such a belief may be false. Similarly, despite overwhelming evidence that contravenes a belief, such a belief nevertheless may, on this correspondence conception, be true. The indoctrinator, who is intent on defending his or her practice, can do so by noting and exploiting the logical gap that a certain conception of correspondence allows between truth and evidence. So no matter what sort of claptrap an indoctrinator may resort to in persuading students of the truth of the beliefs he or she is teaching, any counter-evidence resulting from genuine inquiry can be safely ignored. For the truth of these beliefs is viewed as logically independent of, and thus protected from, any countervailing considerations.

What, then, is the particular version of correspondence that allows an indoctrinator to view the truth of a belief as logically independent of evidence? Whatever interpretation we finally give to correspondence, the one constraint on it, if we are to go beyond platitude, is that it needs to connect belief with the way things are. It is this connection between belief and reality that gives the correspondence conception of truth its appeal. But it is an open question whether we define 'true' in terms of a belief-independent reality or characterize the 'real' in terms of what is found to be true. If we choose the latter, we are still left with the job of defining truth. A self-acknowledged indoctrinator, however, chooses the first version of correspondence. In characterizing 'truth' in terms of the real, he

\footnotetext{
${ }^{4}$ Obviously not all indoctrinators acknowledge, even to themselves, the nature of their teaching practices. Later, I
} will consider unacknowledged indoctrination. 
or she allows the possibility that beliefs can be true independently of how we might find the truth. What is so unsatisfactory about this version of truth as correspondence is that it leaves us with an undefined notion of what constitutes a belief-independent reality. In contrast to this, the second version of correspondence defines what is real in terms of being the object of a belief which is true. If we accept this latter version of correspondence, what we need in addition is a characterization of how reality is belief-independent despite its being defined in terms of true beliefs. We also need to come up with a definition of 'true' which goes beyond correspondence. Can these two things be done without circularity?

Defining reality as the object of true beliefs does not jeopardize the notion that real objects are belief-independent. A red object is not made red by the true belief that it is red. Nor is a virus made into a virus by being correctly believed to be a virus. Real objects are the way they are independently of our beliefs about them even when the latter are true. Defining reality in terms of true beliefs is not intended as a claim about how objects came to be as they are. Rather, it is an epistemic claim about human knowledge and its contact with reality. Accordingly, the definition of reality in terms of the truth of our beliefs makes reality accessible to human inquiry. The same holds for the definition of 'true'. What we need here is an epistemic conception: one which not only connects truth with other beliefs serving as evidence, but one which also specifies some of the norms governing the practice of belief formation and revision. Satisfying these norms means that an inquiry has been well done. The convergence conception of truth, proposed by C.S. Peirce, satisfies the requirements of an epistemic conception of truth. In the Peircian conception of truth, if a proposition is true, then if an inquiry relevant to that proposition were to be pursued as far as it could fruitfully go, then that proposition would be believed by all those who competently investigate. ${ }^{5}$ Or, as Peirce himself succinctly put it, the "opinion which is fated to be ultimately agreed to by all who investigate, is what we mean by the truth...." 6

While this convergence conception of truth leaves no gap between truth and evidence, it does not require, in order to reach the ideal limit of inquiry, that inquirers have all possible relevant evidence. What is required, however, is that a belief when true is fixed and stable and therefore cannot be upset by any further evidence. Although this latter point makes Peirce's fixed beliefs sound like the indoctrinated state of mind with its disposition to reject any countervailing consideration, it is quite different due to Peircian fallibilism. Because of fallibilism, inquirers have no absolute guarantee that they have indeed reached the ideal limit of inquiry. If, however, they were to do so, no further evidence could upset that belief since, after all, it is true.

How does truth as convergence help specify the norms that govern inquiry? Of course, because of fallibilism, convergence itself is not a norm, since beliefs are not true because inquirers agree on them. Rather, it is because beliefs are true that competent inquirers would, in the long run, come to agree on them. Since, for Peirce, the object represented by a true belief is a reality, ${ }^{7}$ convergence, if it were to occur, would do so if inquiry were such as to allow belief-independent reality to influence the formation of beliefs. Appealing to a belief-independent reality is not a covert reintroduction of the indoctrinator's version of the correspondence conception of truth. Rather, such an appeal is meant to explain how convergence on true beliefs is made possible. An inquiry which allows a belief-independent reality to influence the formation of beliefs while not giving absolute guarantees nevertheless provides inquirers with good grounds for their hope that convergence would occur if inquiry were pursued as far as it could fruitfully go.

\footnotetext{
5 This is a slight modification of a version of the convergence conception found in C. Misak's Truth and the End of Inquiry (Clarendon Press: 2004, $2^{\text {nd }}$ edition. pp. 43-44.

${ }^{6}$ C.P. 5.407. The reference is to the Collected Papers of Charles Sanders Peirce, (eds.) C. Hartshorne and P. Weiss (1931-35), Volume 5, Paragraph 407. (Harvard University Press)

7 ibid.
} 
A second way that convergence specifies the norms governing inquiry arises from the cooperative nature of inquiry. Convergence involves all those who inquire about a particular problem and would occur if they were to investigate well enough and long enough. When disagreements occur among those who investigate competently, these differences should be recognized and dealt with. Unlike the indoctrinated person, a competent inquirer is not expected to treat those who raise difficulties as either fools or knaves, but rather as competent members of a community of inquirers.

Before leaving this section, I want to consider at least one objection to the convergence conception of truth. This objection arises in connection with the idea that there may be truths forever hidden from inquiry. So, for example, propositions such as "There were 17 copies of Aristotle's Poetics in the ancient library at Alexandria" or "Julius Caesar sneezed sixteen times while crossing over to Britain during the first Roman invasion" are either true of false, even though it is unlikely that any inquiry could be fruitfully conducted to settle these matters. So it looks as if there could be truths which are independent of possible convergence by inquirers.

This attempt to separate our conception of truth from inquiry does not simply claim that there may be truths which are hidden because our current ability to conduct inquiry into certain matters is limited. If the convergence conception is unsatisfactory, the argument needs to show that there are truths which are forever hidden from those who would be able to conduct any future inquiry. Yet, as Peirce reminds us at the end of his "How to Make Our Ideas Clear", it is exceptionally hazardous to guess at what any future inquiry can or cannot reveal. He writes that "it is unphilosophical to suppose that, with regard to any given question (which has any clear meaning), investigation would not bring forth a solution of it, if it were carried far enough." 8 The convergence conception of truth, being formulated in the subjunctive conditional, does not exclude the possibility of future investigators converging on truths currently hidden from us. Indeed, it formulates a hope which is reasonable to have. ${ }^{9}$

\section{Fallibilism and Inquiry}

So far I have been concerned with the self-acknowledged indoctrinator and how a certain version of the correspondence conception of truth could be used to provide such a teacher with a protective covering. However, there are many cases of indoctrination which are not recognized as such and indeed are denied to be instances of it. In these cases a teacher, anxious to defend his or her practice as nonindoctrinatory, might resort to the idea that the beliefs being taught are not only important but can also be supported by any genuine inquiry which has been honestly and competently conducted. Such a move would be entirely compatible with the convergence conception of truth and its link to what inquiry would reveal in the long run to all those who investigate.

Any indoctrinator determined to defend his or her teaching as non-indoctrinating would have to justify fostering a disposition to reject any countervailing consideration. To do this, a teacher would need to claim that inquiry has established the beliefs he has taught as beyond the very shadow of doubt. In other words, for such a teacher any inquiry relevant to these beliefs has gone as far as any inquiry can fruitfully go. Therefore, any consideration put forward as countervailing can never have merit. Accordingly, there cannot be any good reason to reappraise, and much less to doubt, the beliefs he or she has taught.

The crucial difficulty with this defense is its supposition that any given inquiry can give us results which are absolutely guaranteed. However, absolute guarantees that no countervailing considerations can have any merit apply only to those beliefs at the ideal limit of inquiry. Such beliefs, in being true,

\footnotetext{
${ }^{8}$ Op cit C.P. 5.409

9 The last several paragraphs owe a great deal to Christopher Hookway's Truth, Rationality, and Pragmatism (Clarendon Press: Oxford; 2000). Chapter 2.
} 
cannot be upset by any further evidence. But since we cannot achieve any absolute guarantee that for any particular inquiry we have indeed reached that ideal limit, the beliefs we accept as a result of inquiry can become subject to future countervailing considerations and thus become subject to doubt or revision.

A teacher who recognizes the fallibility of human inquiry should develop in his or her students an outlook which differs markedly from that of someone who has been indoctrinated. The beliefs, skills, and dispositions a non-indoctrinating teacher chooses to foster should be based on the best, though fallible, results which various forms of inquiry have so far achieved. The differences and disagreements which arise within a given community of inquirers are not treated as the outpourings of deluded fools, but as representative of the current, though fallible, condition of inquiry.

To develop an outlook consistent with fallibility is not the same as encouraging skepticism within students. Fallibilism, while denying that there are absolute guarantees, nonetheless can inspire in students the hope that the ideal limit may yet be reached and in some cases may have already been achieved. Skepticism, however, regards such a hope as a delusion. Later, I will consider epistemic prudence as one virtue consistent with fallibilism which stands in need of being encouraged in students. This particular virtue is a condition which lies in an intermediate position between two intellectual vices - credulity and absolute skepticism - neither of which is to be fostered.

\section{The Value of Inquiry}

Given the convergence conception of truth, in being indoctrinated one is prevented, if the ideal limit has indeed been reached, from acquiring evidenced-based beliefs which are true. But, considering that there are no absolute guarantees that we have reached such a limit, in indoctrinating students a teacher is blocking students from acquiring the best approximation to the truth that we currently have. So the problem in being indoctrinated is that it is contrary to the best way we have of getting at the truth. But are we better off in having true beliefs, rather than being in error about how things are, especially if our illusions are comforting? And, if we are better off in having beliefs which are true, is their value restricted to those beliefs which are merely useful in directing a person towards the beneficial and away from the harmful?

Suppose we consider the non-instrumental value of having true beliefs by way of considering why truthfulness in a person is rightly considered to be a virtue. Certainly a teacher who has indoctrinated his or her students lacks truthfulness. Such a teacher has, whether knowingly or not, deceived students as to the cognitive status, within a particular community of inquirers, of those beliefs which he or she has taught. For example, since the community of historical inquirers diverges from those anti-Semitic beliefs taught as true by someone like James Keegstra, ${ }^{10}$ teaching such beliefs amounts to deceiving students about what historians accept. So truthfulness, especially in a teacher, involves an unwillingness to deceive students. But since a teacher might be self-deceived as to the status of the beliefs he or she is teaching, an unwillingness to deceive requires that trouble be taken by a teacher in the formation, maintenance, and revision of those beliefs he or she is prepared to pass on as true. A teacher can take the required trouble by being adequately familiar with what a particular community of inquirers currently converges on as well as how they diverge from one another. A teacher then needs to exercise what Bernard Williams has called "epistemic prudence" especially

\footnotetext{
${ }^{10}$ For brief accounts of the Keegstra case see William Hare's article "Limiting the Freedom of Expression: The Keegstra case" in Hare's Attitudes in Teaching and Education (Detselig Enterprises; 1993) pp. 75-88. See also Jonathon Glover's Humanity (Pimlico; 2001) pp. 362-364.
} 
concerning those beliefs where wishful thinking may lead to self-deception and thence to the deception of students. ${ }^{11}$

True beliefs are inherently good in so far as the believer is in an undeceived condition about how things are. Being able to inquire into beliefs is a way of taking a certain amount of care over our beliefs so as to avoid being deceived. When it comes to beliefs which have a significant bearing of how one lives, epistemic prudence is especially important. For when it comes to acquiring personal, social, and political self-understanding, ${ }^{12}$ wishful thinking can provide ample opportunity for self-deception. Moreover, others seeking power and influence can, and often do, resort to deliberate deception. In short, one aspect of the value of inquiry is that it is an exercise in epistemic prudence.

\section{Sincerity and Accuracy}

Teachers, who initiate students into various forms of inquiry, can, simultaneously exemplify and foster the various ways in which epistemic prudence can be exercised. But since epistemic prudence is a prophylactic against deception of any kind, it is exercised by someone functioning as an intelligent critic of instances of inquiry. A teacher of one of the various forms of inquiry need not, in order to be a good teacher, turn out competent investigators. He or she need only develop in students a competence to appraise, up to a certain level, the truthfulness of others. ${ }^{13}$ In what follows I am going to suggest that, at a minimum, what a student needs to acquire in order to make appraisals of truthfulness is the ability to make reliable judgements concerning sincerity and accuracy. ${ }^{14}$

To illustrate how judgements of sincerity and accuracy combine to make judgements about truthfulness, consider the following simple case. Suppose B tells A that a tiger has recently escaped from the local zoo and has just been spotted two streets from where they are currently standing. How then is A to judge the truthfulness of B's report, given that A himself or herself is in no advantageous position to judge these matters directly? First, there is the issue of B's sincerity: that is, is B telling A what he, $\mathrm{B}$, believes is true? Does $\mathrm{B}$ have any reason to deceive or conceal? But secondly, even if it turns out that $\mathrm{B}$ is sincere, one should still ask whether his report is accurate. Here the obvious question to ask of $\mathrm{B}$ is how did he come by the beliefs he has; was it by direct observation, the testimony of others, or some other means? Furthermore, the accuracy of B's account becomes more likely in the eyes of $A$ to the extent that others, independently of $B$ and each other, tell and sincerely believe the same story as does B. As we can see, judgements about the truthfulness of others often come down to judgements about their trustworthiness.

One final note. Judgements of sincerity and accuracy can also be applied to teachers, though usually students, especially young ones, are in no position to do so. Does a teacher sincerely believe that what he or she is teaching is true? And, if so, how did the teacher come to his or her beliefs? Does his or her teaching reflect an accurate view of what inquirers have or have not converged upon? Or, are the beliefs being taught due to bias and/or ideological preferences? A teacher who has indoctrinated students may be sincere, although his or her accuracy as to the epistemic status of the beliefs being taught is defective. Such a teacher, in disposing students to reject any consideration which countervails

\footnotetext{
${ }^{11}$ For Williams' use of this phrase see his “Truth, Politics, and Self-Deception” in B. Williams In the Beginning Was the Deed (Princeton University Press: 2005) p. 156.

12 B. Williams, Truth and Truthfulness (Princeton University Press; 2002) p.6.

13 The qualification "up to a certain level" is important. It would not be reasonable to expect someone like a history teacher to turn out students who could operate at the same level of competence as a professional historian when functioning as a critic of the work of his or her fellow historians.

14 For the notions of sincerity and accuracy as well as their connection with truthfulness, I am indebted to Bernard Williams' Truth and Truthfulness.
} 
against the beliefs that he or she has taught, is failing to foster epistemic prudence. Yet, being epistemically prudent is significant in a world where deceit and concealment are hardly unknown.

\section{About the Author}

Paul O'Leary is a professor emeritus at the University of Western Ontario. He has published articles in such journals as: The Transactions of the Charles S. Peirce Society, Educational Theory, Canadian Journal of Education, Studies in Philosophy and Education and Paideusis. He is currently investigating a virtue-based moral education as well as the connection between teaching and the ethics of belief. 